\title{
Integrating Property Industry in Masters Real Estate Education in Africa: Approaches and Initiatives
}

\author{
Dr Samuel H.P. Chikafalimani \\ Property Valuer / Property Industry Specialist, Industrial \\ Development Corporation of South Africa \\ Email: samuelc@idc.co.za \\ Mr Ganesan Reddy \\ Head of Department, Department of Construction Management and Quantity Surveying \\ Faculty of Engineering and the Built Environment, \\ Durban University of Technology, South Africa \\ Email: reddyg@dut.co.za
}

Doi:10.5901/mjss.2014.v5n20p340

\section{Abstract}

Programme coordinators and their assistants within selected Masters Real Estate (MRE) programmes offered in Africa were surveyed to determine approaches and initiatives adopted to integrate the property industry in real estate curriculum and research. Results reveal that involvement of part-time lecturers from industry, inclusion of real-world project cases and practical sessions in the curriculum, appointment of lecturers with high qualifications and industrial experience and deliberate collaboration of research with the industry are some of the practices implemented by the universities to include the industry in the curriculum. Objective of the adopted approaches and initiatives is to produce students and research which are relevant to the property industry and to create other opportunities for students, educators and industry practitioners as they interact in the curriculum. The study intends to support and promote the culture of involving industry practitioners in the curriculum and research in order for the universities to meet property industry requirements in Africa and elsewhere in the world.

Keywords: Masters Real Estate education, property industry

\section{Introduction}

Programme coordinators and their assistants within Masters Real Estate (MRE) degree programmes offered in Africa were surveyed to determine how they are integrating industry practitioners and employers in their curricula and research. While it is appreciated that the universities which are offering the programmes are partnering and involving the industry in one way or another, no study has specifically been done in Africa to investigate the approaches and initiatives adopted by the universities. Therefore, the study aims at describing the approaches and initiatives being implemented to highlight efforts made by the universities in order to graduate competent students who are meeting property industry requirements as well as produce research which is relevant to the industry. In addition, it is believed that such practices would create other opportunities for students, academics and industry practitioners as they interact in the curriculum. The study intends to support and promote the culture of including the industry in real estate curriculum and research in order for the universities to continuously generate graduates and research which are useful to the property industry in Africa and elsewhere in the world. Table 1 below shows selected MRE curricula offered in Africa.

\section{Literature Review}

A number of educators and researchers have conducted studies focusing on integration of the property industry in real estate education. Black, Carn, Diaz \& Rabianski (1996) emphasise that any well-rounded real estate curriculum must reflect the interdisciplinary and multidisciplinary nature of the property industry. In addition, a real estate curriculum should recognise the different constituents in the industry whose needs and concerns must be met. Therefore, the aim of a real estate curriculum should be to provide effective real estate decision makers and managers who are armed with the concepts, techniques and skills required to solve problems in the property industry of today and tomorrow. This can be 
achieved only when educators involve the industry practitioners in the curriculum since they have the experience and are much aware of what is required for a real estate professional to be efficient and effective at the workplace (Chikafalimani \& Cloete, 2010; Ooi \& Yu, 2011; Jayantha \& Chiang, 2012; Chikafalimani, 2013).

Table 1: Selected Masters Real Estate programmes offered in Africa

\begin{tabular}{|c|c|c|c|c|c|}
\hline University \& Dept / School & Name of degree & Admission requirements & Duration & Delivery & Total credits \\
\hline $\begin{array}{l}\text { Pretoria } \\
\text { (Construction Economics), } \\
\text { South Africa }\end{array}$ & MSRE & $\begin{array}{l}\text { Hons, } 4 \text { or } 5 \text { yr relevant } \\
\text { bachelors degree } \\
\text {.Work experience }\end{array}$ & 2 yrs \& treatise & 8 block weeks & 180 \\
\hline $\begin{array}{l}\text { Witwatersrand } \\
\text { (Construction Economics \& } \\
\text { Management) }\end{array}$ & MSPDM & $\begin{array}{l}\text { Relevant good bachelors } \\
\text { degree } \\
\text {.Work experience }\end{array}$ & $\begin{array}{l}1 \text { yr full time, } 2 y r s \\
\text { part time \& treatise }\end{array}$ & $\begin{array}{l}1 \text { week block } \\
\text { release }\end{array}$ & 240 \\
\hline $\begin{array}{l}\text { Cape Town } \\
\text { (Construction Economics \& } \\
\text { Management), South Africa }\end{array}$ & MSPS & $\begin{array}{l}\text {.Hons or } 4 \text { yr relevant } \\
\text { bachelors degree } \\
\text {.Work experience } \\
\end{array}$ & 2 yrs \& treatise & Block system & 200 \\
\hline $\begin{array}{l}\text { Free State } \\
\text { (Quantity Surveying \& } \\
\text { Construction Management), } \\
\text { South Africa }\end{array}$ & MPS & $\begin{array}{l}\text { Relevant good bachelors } \\
\text { degree }\end{array}$ & 2 yrs \& treatise & $\begin{array}{l}8 \text { workshop } \\
\text { weeks }\end{array}$ & 200 \\
\hline $\begin{array}{l}\text { Nelson Mandela Metropolitan } \\
\text { (Construction Management \& } \\
\text { Quantity Surveying), South } \\
\text { Africa }\end{array}$ & MSBE & $\begin{array}{l}\text {.Relevant good bachelors } \\
\text { degree } \\
\text {.Work experience }\end{array}$ & $\begin{array}{l}1 \text { yr full time, } 2 \text { yrs } \\
\text { part time \& treatise }\end{array}$ & $\begin{array}{l}4 \text { or } 5 \text { block } \\
\text { weeks }\end{array}$ & 202 \\
\hline $\begin{array}{l}\text { Obafemi Awolowo (Estate } \\
\text { Management), Nigeria }\end{array}$ & MSEM & $\begin{array}{l}\text { At least relevant second class } \\
\text { honours degree } \\
\text {.Work experience }\end{array}$ & 12 months \& treatise & $\begin{array}{l}1 \text { week block } \\
\text { release }\end{array}$ & $\begin{array}{l}24 \text { course } \\
\text { units }\end{array}$ \\
\hline $\begin{array}{l}\text { Nairobi (Real Estate and } \\
\text { Construction Management), } \\
\text { Kenya }\end{array}$ & MAVPM & $\begin{array}{l}\text { At least relevant second class } \\
\text { honours degree } \\
\text {.Work experience }\end{array}$ & 2 yrs \& treatise & Full time & 900 hours \\
\hline Ardhi (Real Estate), Tanzania & MSRE & $\begin{array}{l}\text { At least second class relevant } \\
\text { good bachelors degree }\end{array}$ & 2 yrs \& treatise & $\begin{array}{l}\text { Full time \& } \\
\text { Part time }\end{array}$ & 40 \\
\hline
\end{tabular}

Key: MSRE: Master of Science in Real Estate. MSPDM: Master of Science in Property Development and Management MSPS: Master of Science in Property Studies. MPS: Masters in Property Science

MSBE: Master of Science in Built Environment. MSEM: Master of Science in Estate Management MAVPM: Master of Arts in Valuation and Property Management

Sources: Real Estate Study Guides Universities of Pretoria, Witwatersrand, Free State, Cape Town, Nelson Mandela Metropolitan, Nairobi, Ardhi and Obafemi Awolowo (2014)

Butler, Guntermann \& Wolverton (1998) applaud the teaching approach adopted when real estate practitioners are integrated in the curriculum. They comment that the teaching approach tends to change from the traditional passive text book educational delivery system to active and real-world experience approach. This approach of learning is practical and supports the process of preparing high quality and competent students who are able to function successfully in the industry due to its ability to confront reality. The employers who eventually hire the graduates appreciate this learning approach since they expect the new employees to be able to work independently in an active environment of changing concepts, new technology and collaborative relationships. The active practical learning approach also minimises on-thejob orientation and training time the employers spend on freshly recruited graduates based on the fact that the graduates have already obtained some job clues while in the university.

Worzala (2003) laments that not all research which the academics are undertaking involves and addresses the challenges the property industry is facing. As a result the industry is reluctant to fund university research since it is irrelevant. She insists that industry players have to make profit and have research priorities which they want academics to investigate to assist them solve industry problems. Therefore, when the industry is integrated it is easy and possible for real estate practitioners to contribute sensibly towards formulation of important research work the academics and students can do which directly solves significant problems the industry is facing. This relationship can also encourage research collaborations between academics and the industry. In the process fund raising by academics for research output would be easier since the expected research findings and results will be of great interest to the industry and real estate business in general. 
Apart from graduating students and offering curricula and producing research which are industry-related Hakfoort, Berkhout \& Manshanden (2003) and Chambers, Holm \& Worzala (2009) emphasise that integration of the industry into the curriculum offers other benefits too. They observe that integration of the industry into the curriculum can create extra opportunities for students while they are pursuing their studies at the universities and after graduation. These opportunities include: scholarships, mentorships, industrial attachments, work experience, employment, data collection for assignments and projects, and networking opportunities.

Isakson, Rabianski \& Schulte (2003) comment on the significant role played by real estate accreditation and professional bodies in making sure that the industry is integrated in the curriculum. Accreditation bodies achieve this role in the processes of real estate curriculum scrutinisation to ensure that teaching, research and curriculum content are of high quality in order to meet property industry requirements. In so doing the public, clients and employers are assured that the graduates produced from accreditated programmes are of high quality and competent. Suggestions and inputs given during accreditation exercises are critical in addressing weaknesses of real estate programmes to make sure the curricula are acceptable by the industry. One important aspect assessed during the accreditation visits is the involvement of industry practitioners in the curriculum. The other duty of accreditation bodies is to enforce and regulate laws responsible for governing issues related to real estate professionals, observance of professional ethics, and continuous professional development. Isakson, Rabianski \& Schulte (2003) note that internationally, the Royal Institution of Chartered Surveyors (RICS) is a good example of a professional body which has greatly influenced real estate curricula offered in different parts of the world to incorporate the industry in their course offerings as a condition to receive accreditation status.

Some authors including Chambers, Holm \& Worzala (2009) have examined the gap between property industry and real estate education, and have spent a lot of effort in trying to bridge this gap. This is partially aimed at addressing the criticism that universities are not always teaching students what the industry wants and are conducting research which is irrelevant to the industry (Souza, 2000; Manning, 2002). Worzala (2003) indicates that in response to this criticism, some universities in USA and Pacific Rim that are offering real estate programmes have deliberately collaborated with the industry to produce research which answers directly the challenges the industry is facing. They have also introduced innovative approaches and initiatives in the curriculum to bring the outside industry into the real estate classroom in order to meet industry requirements. Reviewed literature shows that several educators and researchers have undertaken studies to identify the practices these universities have implemented to integrate the industry in the curriculum (Callan \& McCarthy, 2003; Worzala, 2003; Galuppo \& Worzala, 2004; Delaney \& Rose, 2007; Chambers, Holm \& Worzala, 2009; Chikafalimani, 2013; Chikafalimani \& Reddy, 2014). For purposes of this study, these practices are summarised below and are divided into three main categories: approaches and initiatives that can be adopted by (i) universities, (ii) industry practitioners and employers, and (iii) professional and accreditation bodies.

(i) Approaches and initiatives that can be adopted by universities:

- Involve guest lecturers, motivational speakers, alumni and other industry practitioners to teach in the curriculum.

- Employ lecturers with industrial experience.

- Consider offering sabbatical leave and industrial secondments to teaching staff.

- Involve industry practitioners in curriculum review, improvement and development.

- Include project-related courses, case studies and real-life projects in the curriculum.

- Create opportunities for students in the curriculum, for example through: industrial attachments and educational tours.

- Emphasise on research which is relevant to the industry to easily get research funding and grants from the industry.

- Consider better research package delivery products like research reviews and summaries.

- Encourage research collaborations with the industry to enrich research products.

(ii) Approaches and initiatives that can be adopted by industry practitioners and employers:

- Consider to volunteer teaching at universities offering real estate programmes due to shortage of staff.

- Continue to get involved with your previous real estate programmes. This is good opportunity for the alumni.

- Create and offer students employment and industrial attachment opportunities.

- Support academic staff and students with data for teaching, assignments and projects.

- Support professional registration, supervision and mentoring of students and new graduates.

- Give financial assistance to real estate programmes and students. 
(iii) Approaches and initiatives that can be adopted by professional and accreditation bodies:

- Continue to promote interaction of students, educators and industry practitioners by facilitating seminars and conferences.

- Continue promotion of the involvement of the industry in accreditation exercises for real estate programmes.

While an integrated real estate programme has tremendous potential to enhance educational experience of students and encourage production of industry related research, this innovative educational and research approach faces a number of problems to be effectively implemented by the universities (Butler, Guntermann \& Wolverton, 1998; Worzala, 2009). The first challenge relates to the time demanded by the industry for academics to produce research findings. Academics are usually under pressure from the industry to submit research results immediately. However, sometimes due to the complexity of the research problems to be solved, it may not be possible for academics to give the industry the results at short notice. This normally does not go well with industry players who need the results urgently so that they can apply them in their real estate business and profit making decisions. The second challenge is that integration of the industry into the curriculum relies heavily on supportive university administrations and procedures. Finally, inclusion of the industry into the curriculum requires enormous commitment of time, effort and other resources on the part of faculty, the business community and the university.

\section{Research Methodology}

Two research approaches were used to collect data for the study. Firstly, a literature survey was conducted to collect data from publications focusing on practices to integrate the industry in real estate education. Literature survey was also used to identify MRE curricula offered in Africa by coursework whose course contents were easily accessible. Only eight suitable MRE programmes were identified in the survey. Out of the eight programmes, five are offered in South Africa. This shows that South Africa has more MRE programmes than other countries in Africa. Table 1 contains the selected MRE curricula identified in the survey.

Secondly, a survey of programme coordinators and their assistants within selected MRE degree programmes offered in Africa was undertaken to collect data on the approaches and initiatives the universities considered and implemented to integrate industry practitioners and employers in the curriculum and research. A questionnaire was designed and sent to eight programme coordinators and their assistants for MRE curricula listed in Table 1 to collect data. The questions were simple and leading whereby respondents were asked to answer Yes or No to assist the respondents easily and quickly answer the questions. In terms of classification, the questions were grouped into three main categories: (i) curriculum, teaching and research, (ii) accreditation and professional bodies, and (iii) challenges encountered to integrate the industry. An open ended question was also included to allow respondents mention any comments on the practices followed to integrate the industry. Out of eight questionnaires sent to eight different programme coordinators and their assistants, four questionnaires were returned representing a response rate of $50 \%$.

\section{Results, Analysis and Discussion}

Results of the survey done to determine approaches and initiatives considered and implemented by the universities offering MRE curricula in Africa to integrate the industry in real estate curriculum and research are contained in Table 2 below. The results provide a good basis of comparison of the practices adopted by universities in Africa and other continents to bring the outside industry into the curriculum. For purposes of this study, the results are analysed and discussed under subheadings: curriculum, teaching and research; accreditation and professional bodies; and challenges encountered to integrate the industry.

\subsection{Curriculum, teaching and research}

In the first set of questions MRE programme coordinators and their assistants were asked to confirm practices they have considered and implemented in order to involve industry practitioners in curriculum development and review, teaching and research. Table 2 shows that all respondents (100\%) invited part-ime lecturers, guest specialist lecturers, motivational speakers and former students (alumni) from the industry to participate in teaching of the students in the curricula. This implies that the universities recognize the importance of involving industry practitioners to improve the quality of teaching real estate students from traditionally passive learning to practical active learning. Further, it is also noted that all respondents are including industry practitioners and employers in curriculum development and review 
processes. This is special since it reaffirms that the universities are committed to offering curricula which are relevant and acceptable to the property industry. Interestingly, the results also reveal that all respondents are deliberately including real-world project cases and practical sessions in the curricula in order to graduate students who are competent and ready to hit-the-ground running immediately they join the workplace. This desire is expressed in the way the universities are balancing theory and practice in the curricula. All respondents are also looking for highly qualified and experienced lecturers to be employed at the universities. This is an indication which shows that the universities have trust that highly qualified lecturers with industrial experience add value to the curriculum by bringing new ideas from the industry that are essential for postgraduate students to meet industry desires and requirements. Results in Table 2 also reveal that all respondents are in support of lecturer exchange programmes and professor visitations. This is a positive sign to show that the universities are committed to sharing of real estate knowledge and industrial experiences among the teaching staff and students at universities in different countries of the African continent. Importantly, this would enhance learning experiences of teaching staff and students and their exposure to different property markets. This would compliment efforts being taken to disseminate real estate education and experiences internationally to enable real estate professionals practice competently in different parts of the world since real estate business is now global (Roulac, 2002; Schulte \& Schulte-Daxboek, 2003).

Table 2: Survey responses on integration of the property industry

\begin{tabular}{|c|c|c|}
\hline & Respondents & Percentage (\%) \\
\hline \multicolumn{3}{|l|}{ Curriculum and Research: } \\
\hline Involvement of part-time lecturers from industry & 4 & 100 \\
\hline Invitation of guest specialist lecturers & 4 & 100 \\
\hline Invitation of motivational speakers & 4 & 100 \\
\hline Involvement of alumni (former students) & 4 & 100 \\
\hline Supporting student industrial attachments & 4 & 100 \\
\hline Promoting career functions & 4 & 100 \\
\hline Encouraging educational tours / field trips & 2 & 50 \\
\hline Including real-world project related cases & 4 & 100 \\
\hline Deliberately including practical sessions in the curriculum & 4 & 100 \\
\hline Employing lecturers with high qualifications and industrial experience & 4 & 100 \\
\hline Involving industry practitioners in curriculum development and review & 4 & 100 \\
\hline Promoting research partnerships with industry practitioners and employers & 2 & 50 \\
\hline Conducting consultancies & 2 & 50 \\
\hline Organising seminars and conferences & 2 & 50 \\
\hline Arranging social meetings and events & 2 & 50 \\
\hline Encouraging industry to support students with bursaries & 2 & 50 \\
\hline Organising best student, lecturer or practitioner awards & 2 & 50 \\
\hline Promoting student exchange programmes & 2 & 50 \\
\hline Supporting lecturer exchange programmes & 4 & 100 \\
\hline Encouraging professor visitations & 4 & 100 \\
\hline Considering industrial attachments for lecturers & 2 & 50 \\
\hline \multicolumn{3}{|l|}{ Accreditation and professional bodies: } \\
\hline Offering curriculum approved by accreditation bodies & 4 & 100 \\
\hline Ensuring that curriculum requirements recommended by accreditation bodies are always met & 4 & 100 \\
\hline $\begin{array}{l}\text { Considering input given by other professional associations on new innovations to be included } \\
\text { in the curriculum }\end{array}$ & 4 & 100 \\
\hline \multicolumn{3}{|l|}{ Challenges encountered to integrate the industry: } \\
\hline Reluctance by the industry to offer support & 4 & 100 \\
\hline Limited resources including funding and lecturing staff & 4 & 100 \\
\hline Tight university calendar & 4 & 100 \\
\hline University administration, policies and procedures & 4 & 100 \\
\hline
\end{tabular}

From Table 2 it is also observed that only $50 \%$ of the respondents are: promoting research partnerships with industry practitioners and employers; conducting consultancies; and organizing seminars and conferences, social meetings and events. In relation to this aspect, one of the respondents commented through an open-ended question that it was difficult for universities to promote partnerships with the industry in these areas due to a number of challenges which include: communication problems between academics and industry practitioners, limited resources including funds, and tight work schedules for both academics and industry practioners. As a consequence academics and industry practitioners tended 
to operate separately. Results in Table 2 also reveal that only $50 \%$ of the respondents supported student industrial attachments, career functions and educational tours for postgraduate students. In a separate discussion, with one of the respondents, it was noted that this could be due to the fact that most students registered for MRE programmes were mature students who are already working. Based on this the universities considered it unnecessary to implement these practices since it was assumed that postgraduate students are already experienced and aware of what is expected at the workplace. In Table 2 it is also noted that $50 \%$ of the respondents are not involved in promotional activities to encourage the industry to support students with bursaries. This could again be based on the fact that most MRE students are working and are able to raise adequate funding on their own for their studies. $50 \%$ of the respondents are also not interested in organising awards for best students, lecturers and industry practitioners. As expected, $50 \%$ of the respondents are also not in support of industrial attachments for lecturers. One of the respondents argued that some lecturers own private property consultancy firms which enabled them remain in touch with industry practices; therefore there was no need to promote industrial attachments for lecturers.

\subsection{Accreditation and professional bodies}

In the second set of questions, MRE programme coordinators and their assistants were asked to comment on their involvement with accreditation and professional bodies in the curriculum. Results in Table 2 show that all universities make effort to offer curricula which are approved and accredited by relevant accreditation and professional bodies in their countries and internationally. This is a strong indication that the universities are aware of the benefits of offering accredited curricula to their students. It also shows that they do understand the influence which accredited curricula have on students, employers and the general public. Further, this proves that the universities are appreciating the valuable input given by accreditation bodies during accreditation exercises to ensure that the industry is integrated in the curriculum and research. Some of the respondents also added that when their curricula are accredited the status of the universities and the curricula is elevated in the eyes of the public and it is a strong marketing tool for prospective students to enroll for the programmes since prospective students are aware that they will easily get employed when they graduate from the programmes. Table 2 also reveals that all universities are ensuring that curriculum requirements recommended during accreditation visits are implemented in their curricula. It is also noted in Table 2 that all respondents seriously consider all other comments made by other relevant professional associations on new innovations to be included in the curricula to improve their quality and meet student and industry requirements.

\subsection{Challenges encountered to integrate the industry}

Results in Table 2 confirm the findings of Butler, Guntermann \& Wolverton (1998) that while an integrated real estate curriculum has tremendous potential to enhance educational experience of students and encourage production of industry related research, it faces a number of problems to be properly implemented. The first challenge reported by all respondents in this study is that industry practitioners tend to be reluctant to give necessary support for integration to be achieved in the curriculum and research. This is partly due to busy schedules industry practitioners have in order to manage and maximize profit for their business ventures. Another problem reported by all universities is lack of adequate resources including funding and lecturing staff. Tight university calendars are mentioned in the survey by all respondents as another obstacle to allow effective integration of the industry into the curriculum and research. Finally, university administrations, policies and procedures are also mentioned by all respondents to be a deterrent in some instances towards efforts aimed at achieving inclusion of the industry into the curriculum.

\section{Conclusion}

Based on findings of the study it is indeed noted that a gap exists between the property industry and MRE education in Africa. Due to existence of this gap, the industry has criticized universities offering real estate education for failing to teach students what the industry wants and for conducting research which is irrelevant to the industry. In response, universities offering real estate education have reacted positively to this criticism. They are introducing innovative approaches and initiatives to involve the industry in the curriculum and research in order to meet property industry requirements. These practices include: involvement of part-time lecturers from industry, inclusion of real-world project cases and practical sessions in the curriculum, appointment of highly qualified and experienced lecturers, and deliberate collaboration of research with the industry. However, the innovative approaches and initiatives to integrate industry in the curriculum and research require enormous effort and resources from university administrations, academics, industry 
practitioners and employers. These challenges include: limited financial resources and lack of adequate teaching staff. Despite the demand for resources, findings of the study reveal that integration of the industry into the curriculum and research offers plenty benefits to students, academics and the industry. These benefits justify the efforts to integrate the industry and they include: implementation of relevant curriculum for the industry, generation of industry related research and funds, and creation of several opportunities for students. Consequently, it is recommended that universities offering MRE programmes in Africa continue to involve the industry in the curriculum despite the challenges that are being encountered in the process. It is further recommended that more research be undertaken to determine how best the industry can be integrated in the curriculum. The intention is to make MRE education in Africa continuously meet property industry requirements and to bridge the gap between industry and real estate education. Finally, it is also noted that the approaches and initiatives identified in this study are generally similar to practices adopted by other universities internationally in order to integrate the property industry into real estate education.

\section{References}

Ardhi University, Department of Land Management and Valuation, Master of Science Degree in Real Estate Brochure (2014).

Black, R.T.; Carn, N.G.; Diaz, J. \& Rabianski, J.S. (1996), The Role of the American Real Estate Society in defining and promulgating the study of real property, Journal of Real Estate Research, Vol. 12 No. 2, pp. $183-193$.

Butler, J.H; Guntermann, K.L. \& Wolverton, M. (1998), Integrating the Real Estate Curriculum, Journal of Real Estate Practice and Education, pp. $51-66$.

Callanan, J. \& McCarthy, I. (2003), Property Education in New Zealand: Industry Requirements and Student Perceptions, Journal of Real Estate Practice and Education, Vol. 6 No. 1, pp. $23-32$.

Chambers, L.; Holms, J. \& Worzala, E. (2009), Graduate Real Estate Education: Integrating the Industry, International Journal of Property Studies, pp. 1-13.

Chikafalimani, S.H.P. (2013), Curriculum Guideline for Masters Real Estate Education in South Africa, Academic Journal of Interdisciplinary Studies, Vol.2 No.3, pp. 397- 402

Chikafalimani, S.H.P. \& Cloete, C.E. (2010), Property Industry Perceptions on Time Allocation to Masters Real Estate Topics in South Africa, Journal of Real Estate Practice and Education, Vol. 13 No. 1, pp. 23 - 32.

Chikafalimani, S.H.P. \& Reddy, G. (2014), Importance of Integrating the Industry in Masters Real Estate Education in Africa, paper presented at the TG59 People in Construction Conference, 6-8 April 2014, Port Elizabeth, South Africa.

Delaney, J.T. \& Rose, C.J. (2007), Case Studies in Real Estate Education: the new AACSB Accreditation Standards and a Proposed Case Study in Real Estate Management, Journal of Real Estate Practice and Education, Vol. 10 No. 2, pp. 175 - 186.

Galuppo, L.A. \& Worzala, E. (2004), A Study into the Important Elements of a Masters Degree in Real Estate, Journal of Real Estate Practice and Education, Vol. 7 No. 1, pp. 25 - 42.

Hakfoort, J.; Berkhout, P. \& Manshanden, W. (2003), The Demand for Professional Education: Evidence from the Dutch Real Estate Industry, Journal of Real Estate Practice and Education, pp. 5 - 21.

Isakson, Rabianski \& Schulte (2003), The Accreditation of Collegiate Real Estate Education Programs in the United States and the European Union, paper presented at the Pacific Rim Real Estate Society Conference, 19-22 January 2003, Brisbane, Australia.

Jayantha, W.M. \& Chiang, Y.H. (2012), Key Elements of Successful Graduate Real Estate Education in Hong Kong, Journal of Real Estate Practice and Education, Vol. 15 No. 2, pp. 101 - 110.

Manning, C. (2002), Improving Real Estate and Other Business Courses through Targeted Student Assessment, Journal of Real Estate Practice and Education, Vol. 5 No. 1, pp. 27 - 43.

Nelson Mandela Metropolitan University, Department of Construction Management and Quantity Surveying, Master of Science in the Built Environment Study Guide (2014).

Obafemi Awolowo University, Department of Estate Management, Master of Science Degree in Estate Management Brochure (2014).

Ooi, J.T.L. \& Yu, S. (2011), Graduate Real Estate Education in Singapore: What Prospective Students Look for, Journal of Real Estate Practice and Education, Vol. 14 No. 1, pp. $35-52$.

Roulac, S.E. (2002), Requisite Knowledge for Effective Property Involvements in the global context, in monograph of Real Estate Education Throughout the World: Past, Present and Future, SchulteK.-W. (editor) (2002). Kluwer Academic Publishers.

Schulte, K.-W. \& Schulte-Daxboek, G. (2003), Internationalisation of Real Estate Education, paper presented at Pacific Rim Real Estate Society Conference, 19-22 January 2003, Brisbane, Australia

Souza, L.A. (2000), Academic and Applied Real Estate Research: As the Two Worlds Collide or As the Two Worlds Divide? Journal of Real Estate Portfolio Management, Vol. 6 No. 1, pp. 97 - 100.

University of Cape Town, Department of Construction Economics and Management, Property Studies Guide (2014).

University of Nairobi, Department of Land Development, Master of Arts in Valuation and Property Management Study Guide (2014).

University of Pretoria, Department of Construction Economics, Real Estate Study Guides (2014).

University of Witwatersrand, School of Construction Economics and Management, Postgraduate Handbook (2014).

Worzala, E.M. (2003), Bridging the Practical / Academic Divide in Real Estate, Pacific Rim Property Research Journal, Vol. 8 No. 1, pp. 3 - 14. 